\title{
Prevalence and Pattern of Work Place Bullying as Psychosocial Hazards among Workers in a Tertiary Institution in Nigeria
}

\author{
Aborlo Kennedy Nkporbu ${ }^{1}$, Kingsley Enyina Douglas ${ }^{2}$ \\ ${ }^{1}$ Department of Neuropsychiatry, University of Port Harcourt Teaching Hospital, Port Harcourt, Nigeria \\ ${ }^{2}$ Department of Preventive and Social Medicine, University of Port Harcourt Teaching Hospital, Port Harcourt, \\ Nigeria \\ Email: " nakpigi2008 yahoo.com
}

Received 5 April 2016; accepted 27 May 2016; published 30 May 2016

Copyright (C) 2016 by authors and OALib.

This work is licensed under the Creative Commons Attribution International License (CC BY). http://creativecommons.org/licenses/by/4.0/

(c) (i) Open Access

\section{Abstract}

BACKGROUND: Work and work environment have enormous influences on both health and production. Psychosocial hazards, including bullying, may be assuming a major place in occupational health and safety, especially in developing countries like Nigeria. Work place bullying, though appears latent, equally appears to receive little attention in workplaces. AIM: The study was to assess the prevalence and pattern of work place bullying among Workers at the University of Port Harcourt. METHODOLOGY: Following approval from the Ethical Committee of the University of Port Harcourt, 600 consenting staffers of the University of Port Harcourt were recruited by systematic random sampling and pretested structured closed ended self administered questionnaires were distributed among respondents. Results were presented via descriptive and analytical methods. RESULTS: Work place bullying was common and verbal abuse was the most prevalent (43.9\%), followed by assigning meaningless tasks unrelated to the employee's job (41.2\%). Risk factors capable of making a worker vulnerable to Work place bullying included work load (98.2\%) as the most prevalent risk factor perceived by the respondents, followed by home-work interface $(82.0 \%)$, lack of possibilities to advance $(70.1 \%)$, interpersonal relationship $(64.0 \%)$. From the study, respondents identified periodic in-service training (PIT) $76.7 \%$, as the most effective possible remedies among others that could be put in place by the University to reduce the prevalence and burden of psychosocial hazards in the University. Conclusion: Work place bullying among workers at the University of Port Harcourt is common occasioned by preventable risk factors. There is need for the University to institute appropriate occupational health and safety measures to reduce the harmful occurrences of psychosocial hazards in the institution in other to improve the working environment.

\section{Keywords}

Bullying, Psychosocial Hazards, Workers, Tertiary Institution

\footnotetext{
${ }^{*}$ Corresponding author.
} 


\section{Introduction}

Every kind of work is associated with its unique certain occupational risks. The changing economic context has been associated with a shift in the types of risks encountered in the work environment, with new types of work place hazards emerging in addition to traditional ones. Emerging workplace risks include psychosocial risks, as well as exposure to a number of new and emerging chemicals and processes of which the consequences for human health are still unknown (e.g., nanotechnology) [1] [2].

Workplace bullying means repeated unreasonable behaviour directed towards an employee or group of employees that creates a risk to health or safety. They include the following; verbal abuse, excluding or isolating particular employees, assigning tasks that are impossible for the employee to successfully complete, harassment or intimidation, assigning meaningless tasks unrelated to the employee's job, changing work rosters with the deliberate intention of inconveniencing particular employees, intentionally withholding information that prevents an employee from effectively discharging his or her duty; and threats of dismissal.

Even though a single incident does not constitute bullying, one-off incidents should not be overlooked. Physical assault (or the threat of physical assault) should be regarded as occupational violence and dealt with accordingly. It has been known that workplace bullying creates an unsafe working environment. Employers must be protective of their employee and ensure, so far as is reasonably practicable, that risks to health and safety from bullying are eliminated or reduced.

Work place bullying consistently shows enormous impact at the level of workers' health, public health and business health. Absenteeism due to occupational injuries or ill health is of growing concern globally, but so is absenteeism due to work-related mental health problems. The health impact from psychosocial risks and workrelated stress affects workers and their families, as well as businesses, since workers' illness is related to outcomes that can have financial impact on businesses. These variables include sickness absences, the hidden cost of presenteism when a sick worker is present at work and not fully productive, and also unemployment. Effects are also visible at national and even global economic levels. Indeed, the cost of the work-related health loss and associated productivity loss represents around 4\% - 5\% of the GDP of most countries [4].

There have been consistent relationships between workplace hazards including bullying and optimal functioning of the worker, organizational productivity and development of work-related ill-health. When a worker is made to operate or function in the right work environment, he or she is most likely to be more productive to the organization. On the other hand, the workers' level of functioning and productivity will reduce if he or she works in a psychosocially hazardous work environment, and in a work place that lacks the needed workers' motivation. Many organizations are concerned with how to increase productivity and in some cases make profit, and in return pay less attention to improving the work place including making it less stressful, and the overall psychosocial health and wellbeing of the worker [4]-[6].

All these factors have been identified to invariably contribute to creating a stressful and an unfriendly work environment and hence increase the risks of psychological problems. Stress is now recognized in health and safety legislation as a workplace hazard, namely a "psychosocial hazard" [7] [8]. This has made workplace stress and employee's optimal functionality, performance and wellbeing, areas of growing importance for organizations, regulators and indeed occupational health and safety [6]. Psychosocial hazards also refer to the mental stresses of work. It equally includes the generally known sources and areas of fatigue and stress that are present in nearly all work places. Psychosocial hazards are inherent in the total stress caused by work, work structure, design and regulation, and therefore is an integral part of an overall assessment of risks at work places.

The impact of these hazards is far enormous on the worker as well as the workplace. They impact negatively on the health and safety of employees and the healthiness and vibrancy of organizations in terms of, among other things, productivity, quality of products and services and general organizational climate. Work place bullying goes hand in hand with the experience of work-related stress. Work-related stress has equally been looked at as the response people may have when presented with work demands and pressures that are not matched to their knowledge and abilities and which challenge their ability to cope and function effectively and productively at work [9]. 
Many studies have associated chronic stress occasioned by work place bullying with a range of negative physical, psychological and social consequences for employees. These include depression, anxiety, burnout, increased alcohol use, smoking, aggression, anger, violence, road rage, poor family interactions, declining marital cohesion [4] [5] [10]-[12], as well as cardiovascular disease, musculoskeletal disorders (MSDs) [13] and hippocampal impairment [4]. Work place hazards have also been associated with high staff turnover and absenteeism, increased industrial accidents and insurance premiums, decreased job performance, loss of productivity and reduce morale among employee [10] [12] [14].

Also, it has been found out that work place bullying can delay recovery from work-related injury/illness and therefore can influence return-to-work outcomes. Sadly, most organizations appear not to pay adequate attention to these social hazards as well as their harmful effects including counter productivity. The worker that persistently labours under the burden of psychosocial hazard is most likely not going to be efficient at work, may lack motivation and likely to operate sub-optimally [15].

It has been noted that $80 \%$ of the global workforce resides in the developing world [16], and is subjected mostly to unhealthy and unsafe working conditions [17]. Published studies point to the fact that traditional risks are intrinsically related to psychosocial risks, since both have the potential for detrimentally affecting social and psychological health as well as physical health [18]. Therefore, psychosocial risks should be considered as risks to both, psychological and physical health [19].

There is currently lack of awareness and this makes most occurrences of work place bullying unnoticed or unattended to [20]. The findings and knowledge from this study will help to create the awareness about psychosocial hazards among workers of the University, and equally afford them the ability to avoid them where and when necessary. The aim of this study therefore was to assess the prevalence and pattern of work place bullying among Workers at the University of Port Harcourt.

\section{Methodology}

\subsection{Study Design}

This is a descriptive cross-sectional study.

\subsection{Study Area and Population}

This study was conducted among 600 workers of the University of Port Harcourt (UNIPORT). Participants were drawn from both academic and non-academic staff of the institution, across Colleges, faculties, Schools and Departments. The University of Port Harcourt, formally known as University College Port Harcourt, is a federal tertiary institution of learning. It was established in 1975 by the Federal Government of Nigeria headed by General Olusegun Obasanjo and was given full University status in 1977. The Motto of the University is Self-reliance and Discipline. The University of Port Harcourt is located along the East-West Road, Choba Town in Obio-Akpor Local Government Area, adjacent the University of Port Harcourt Teaching Hospital, all in Rivers State of Niger Delta Region of Nigeria. Port Harcourt.

The University changed from school system to faculties in 1982. From the time the University was established as University College of Port Harcourt, it has grown from the status of six schools to four Colleges, nine Faculties and four Schools. The Colleges include health sciences, natural and applied sciences, engineering and continuous education while the faculties include those of humanities, pharmaceutical sciences, management sciences, social sciences, law, agriculture, basic medical sciences, clinical sciences and education.

The University currently has staff strength of about four thousand six hundred and fifty five (4655) workers catering for a student's capacity of between 60,000 to 70,000. The University of Port Harcourt, being a federal public educational institution, its work force has been made to as much as possible reflect federal character. The staff categories are along academic and non-academic staff. The academic staff included graduate assistants, assistant lecturers, lecturers 1 and 2, senior lecturers, readers and professors, academic contract staff and those on sabbatical leave. The non-academic Departments/Units include those of Central Administration, Bursary, Library, Works, Security, Transport, Cleaners and Dispatchers. All academic staff are Senior staff while the nonacademic staff are made up of both Junior and Senior staff.

Majority of the study population were enlightened individuals with at least basic educational qualifications.

Only bonafide staff of the University of Port Harcourt, Staff who have given their informed consent, Adults 
aged between 18 years and 70 years and those who had worked not less than 2 years in the University were included while casual staff and less than two years in employment were excluded.

\subsection{Sample Size and Sampling Methods}

The sample size was calculated using the formula for comparison of proportions by Araoye [21]. They consisted of randomly selected staff of all cadres in the work places, made up of both junior and senior staff. A stratified method of sampling was used first and later followed by a systematic random sampling to identify each subject from the various Departments of University of Port Harcourt.

\subsection{Study Instruments}

A well-structured open ended socio-demographic and study questionnaire was used. The structured questionnaire, which was self-administered, was written in simple English and contained sections on socio-demography, psychosocial hazards, possible risk factors and suggested solutions.

A Walk through Survey which is an on the spot, impromptu, unannounced, uninformed, immediate assessment of any work place was also carried out in randomly selected Departments, Units, Offices and other work places in the University.

A pilot study was conducted using sampled population in the Rivers State University of Science and Technology, Port Harcourt, who satisfied the inclusion criteria, and these were not included in the main study.

\subsection{Data Management, Presentation and Analysis}

Analysis of results involved the use of the twentieth edition of the statistical package for social sciences (SPSS20, 2014) software. Descriptive statistics was calculated for all variables. For continuous variables, means and standard deviations (SD) and analysis of variance were computed. For categorical variables, descriptive statistics included the numbers and proportions in each category. Frequency distributions and cross tabulations were generated and chi-square test of significance was calculated. The conventional 5\% of level of significance was set. Confidence interval was set at $95 \%$ and P-value of less than 0.05 was considered statistically significant.

\subsection{Ethical Considerations}

Approval for the study was obtained from the Ethical Committee of the University of Port Harcourt. Consent was equally obtained from all participants. Health education and awareness was carried out for the participants after completing the questionnaires. Meetings were held with staff, management and both staff and management in that other, after the Walk through Survey to intimate them of the outcome.

\subsection{Study Limitations}

The study was limited by the inability to use a walk through survey guide during the walk through survey and the risk matrix in the assessment of risk factors may have undermined the quality of this research work.

\section{Results}

\subsection{Prevalence of Psychosocial Hazards among Workers at the University of Port Harcourt}

From Table 1, among the various forms of workplace bullying, verbal abuse has the highest occurrence with 245 (43.9\%), followed by assigning meaningless tasks unrelated to the employee's job with 230 (41.2\%), then harassment and intimidation with 193 (34.6\%), while excluding or isolating particular employees was 78 (14.0\%). See Table 1.

\subsection{Frequency of Occurrence of Psychosocial Hazards among Workers of University of Port Harcourt}

In the assessment of rate of occurrence of the specific forms of bullying, they were studied under four headings, very regular, regular, occasional and rare (almost does not occur). 
Table 1. Showing the prevalence of bullying among workers at University of Port Harcourt.

\begin{tabular}{|c|c|c|c|c|c|}
\hline \multirow[t]{2}{*}{$\mathrm{S} / \mathrm{N}$} & \multirow{2}{*}{$\begin{array}{l}\text { Psychosocial hazards } \\
\qquad \mathrm{n}=558\end{array}$} & \multirow{2}{*}{$\begin{array}{c}\% \text { of people who } \\
\text { have } \\
\text { experienced } \\
\text { psychosocial } \\
\text { hazards }\end{array}$} & \multirow[t]{2}{*}{$\begin{array}{l}\text { \% who have not } \\
\text { experienced } \\
\text { psychosocial } \\
\text { hazards }\end{array}$} & \multicolumn{2}{|c|}{$\begin{array}{l}\text { Of the number who has } \\
\text { experienced } \\
\text { psychosocial hazards }\end{array}$} \\
\hline & & & & $\begin{array}{l}\text { Junior Stafff } \\
\quad \mathrm{n}=42\end{array}$ & $\begin{array}{l}\text { Senior Staff } \\
\mathrm{n}=516\end{array}$ \\
\hline \multirow{8}{*}{1.} & Work place bullying & & & & \\
\hline & 1) Verbal abuse & 245 (43.9) & $313(56.1)$ & 39 (92.9) & 206 (39.9) \\
\hline & 2) Excluding or isolating particular employees. & $78(14.0)$ & $478(85.7)$ & $26(61.9)$ & $52(10.1)$ \\
\hline & 3) Harassment or intimidation & $193(34.6)$ & $365(65.4)$ & $41(97.6)$ & $152(29.5)$ \\
\hline & $\begin{array}{l}\text { 4) Assigning meaningless tasks unrelated to the } \\
\text { employee's job. }\end{array}$ & $230(41.2)$ & 328 (58.8) & $37(88.1)$ & $193(37.4)$ \\
\hline & $\begin{array}{l}\text { 5) Assigning tasks that are impossible for the } \\
\text { employee to successfully complete. }\end{array}$ & $154(27.6)$ & $404(72.4)$ & $31(73.8)$ & $123(23.8)$ \\
\hline & $\begin{array}{l}\text { 6) Changing work roasters with the deliberate } \\
\text { intention of inconveniencing particular employee. }\end{array}$ & 135 (24.3) & $423(75.8)$ & $27(64.1)$ & $108(20.1)$ \\
\hline & 7) Threats of dismissal & $97(17.5)$ & $461(82.6)$ & $22(52.4)$ & $75(14.5)$ \\
\hline
\end{tabular}

For regular, assigning meaningless tasks unrelated to the employee's job was the most regular in occurrence with $9.1 \%$, followed by Harassment or intimidation with 5.6\%. See Table 2.

\subsection{Pattern of Perpetrations of Psychosocial Hazards among Workers at the University of Port Harcourt}

From the study, all of the forms bullying were perpetrated more by bosses. Assigning tasks that are impossible for the employee to successfully complete was the highest with $98.70 \%$, followed by verbal abuse $(97.07 \%)$. See Table 3.

\subsection{Assessment of the Likely Risk Factors for Bullying as Psychosocial Hazards among Workers at the University of Port Harcourt}

From the study, the most prevalent risk factors for bullying as perceived by workers at University of Port Harcourt was work load with 548 (98.2\%), followed by home-work interface with 458 (82.0\%), lack of possibilities to advance forward 392 (70.1\%), lack of career development 327 (58.7\%), work content with $329(60 \%)$ while poor working atmosphere and lack of interaction were the least with $39.2 \%$ and $29.9 \%$ respectively. See Table 4 .

\subsection{Bullying among Academic and Non Academic Staff of the University of Port Harcourt}

Among the academic staff, 283 (58.84\%) respondents had experienced one form of psychosocial hazards or the other, while of the 77 non academic staff studied, 54 (70.13\%) of them had experienced psychosocial hazards at their workplaces in the University. See Table 5.

\subsection{Suggested Possible Solutions that Could Reduce Bullying at Workplaces in the University of Port Harcourt}

From the study, respondents who identified periodic in-service training (PIT) as a possible solution or preventive measure for reducing prevalence of psychosocial hazards in the University were highest with 428 (76.70\%), followed by enlightenment of University workers with 386 (69.18\%). See Table 6.

\section{Discussion}

From the study, the age group that had the highest prevalence of bullying was age of 26 - 35 years, followed by that of 36 - 45 years. However, the later age group were most represented in the study. This is expected because this age ranges from the most active age of labour with possibly the highest experience and as such, they may be under active pressure to perform and deliver. Suffices to mention that most employers make this age range a criteria for employment [22]. There was a statistically significant relationship between age and experience of 
Table 2. Showing the frequency of occurrence of psychosocial hazards among workers of University of Port Harcourt.

\begin{tabular}{|c|c|c|c|c|c|c|}
\hline $\mathrm{S} / \mathrm{N}$ & Psychosocial hazards & & $\begin{array}{l}\text { Very } \\
\text { Regular }\end{array}$ & Regular & Occasional & $\begin{array}{c}\text { Rare } \\
\text { (does not } \\
\text { occur) }\end{array}$ \\
\hline \multirow{8}{*}{1.} & \multicolumn{6}{|l|}{ Workplace bullying } \\
\hline & 1) Verbal abuse & 558 & $0(0.0)$ & $27(4.8)$ & 218 (39.1) & $313(56.1)$ \\
\hline & 2) Excluding or isolating particular employees. & & $0(0.0)$ & $12(2.2)$ & $66(11.8)$ & $478(85.7)$ \\
\hline & 3) Harassment or intimidation. & 556 & $0(0.0)$ & $31(5.6)$ & $162(29.0)$ & $365(65.4)$ \\
\hline & $\begin{array}{l}\text { 4) Assigning meaningless tasks unrelated to the } \\
\text { employee's job. }\end{array}$ & 558 & $0(0.0)$ & $51(9.1)$ & $179(32.1)$ & $328(58.8)$ \\
\hline & $\begin{array}{l}\text { 5) Assigning tasks that are impossible for the } \\
\text { employee to successfully complete. }\end{array}$ & 558 & $0(0.0)$ & $18(3.2)$ & $136(24.4)$ & $404(72.4)$ \\
\hline & $\begin{array}{l}\text { 6) Changing work roasters with the deliberate } \\
\text { intention of Inconveniencing particular employee. }\end{array}$ & 558 & $2(0.4)$ & $20(3.6)$ & $113(20.3)$ & $423(75.8)$ \\
\hline & 7) Threats of dismissal & 558 & $2(0.4)$ & $7(1.3)$ & $88(15.8)$ & $461(82.6)$ \\
\hline
\end{tabular}

Table 3. Pattern of perpetrations of psychosocial hazards among workers at the University of Port Harcourt.

\begin{tabular}{cccc}
\hline & SOCIAL HAZARDS & \multicolumn{2}{c}{ PERPETRATORS } \\
\cline { 2 - 4 } A & Workplace Bullying & Boss & Surbodinate \\
B & Verbal abuse & $364(97.07 \%)$ & $11(2.93 \%)$ \\
C & Excluding or isolating particular employees. & $136(93.79 \%)$ & $9(6.21 \%)$ \\
D & Harassment or intimidation & $224(96.14 \%)$ & $9(3.86 \%)$ \\
E & Assigning meaningless tasks unrelated to the employee's job. & $313(94.43 \%)$ & $5(1.57 \%)$ \\
& Assigning tasks that are impossible for the employee to & $227(98.70 \%)$ & $3(1.30 \%)$ \\
F & successfully complete & $217(96.02 \%)$ & $9(3.98 \%)$ \\
G & Changing work roasters with the deliberate intention of & $153(96.84 \%)$ & $5(3.16 \%)$ \\
\hline
\end{tabular}

Table 4. Showing likely risk factors of psychosocial hazards among workers at the University of Port Harcourt.

\begin{tabular}{|c|c|c|}
\hline $\mathrm{S} / \mathrm{N}$ & ITEMS & PERCENTAGE (\%) \\
\hline 1 & Changes in the working population (CWP) & 315 (56.5) \\
\hline 2 & Job content (JC) & $329(60.0)$ \\
\hline 3 & Work load (WL) & $548(98.2)$ \\
\hline 4 & Work pace (WP) and Forced pace of work (FPW) & $284(50.9)$ \\
\hline 5 & Work schedule : shift work, long work hours and overtime (WS) & $296(53.0)$ \\
\hline 6 & Control (c) & $216(38.7)$ \\
\hline 7 & Environment and equipment (EAE) & $306(54.8)$ \\
\hline 8 & Organizational culture and function (OCF) & $275(49.3)$ \\
\hline 9 & Interpersonal relationships at work (IRW) & $357(64.0)$ \\
\hline 10 & Violence, threat of violence and bullying at work (VTB) & $281(50.4)$ \\
\hline 11 & Lack of career development (CD) & $327(58.7)$ \\
\hline 12 & Home-work interface (HWI) & $458(82.0)$ \\
\hline 13 & Too busy (TB) & $241(43.1)$ \\
\hline 14 & Lack of possibilities to advance (LPA) & $392(70.1)$ \\
\hline 15 & Lack of job and workplace orientation (LJWO) & $270(48.4)$ \\
\hline 16 & Lack of job descriptions and responsibilities (LJDR) & $267(47.8)$ \\
\hline 17 & Poor management or organization (PMO) & $304(54.5)$ \\
\hline 18 & Poor working atmosphere (PWA) & $219(39.2)$ \\
\hline 19 & Lack of interaction (LI) & 167 (29.9) \\
\hline 20 & Lack of social support (LSS) & $182(32.6)$ \\
\hline 21 & Lack of possibilities to influence decision making (LPIDM) & $269(48.2)$ \\
\hline
\end{tabular}


Table 5. Showing percentage distribution of bullying among academic and non-academic staff of the University of Port Harcourt (Figure 1).

\begin{tabular}{cccc}
\hline Category of Staff & Frequency & \% who have experience & \% not experience \\
Academic staff & 481 & $304(63.20 \%)$ & $177(41.16 \%)$ \\
Non Academic Staff & 77 & $65(84.42 \%)$ & $12(15.58 \%)$ \\
\hline
\end{tabular}

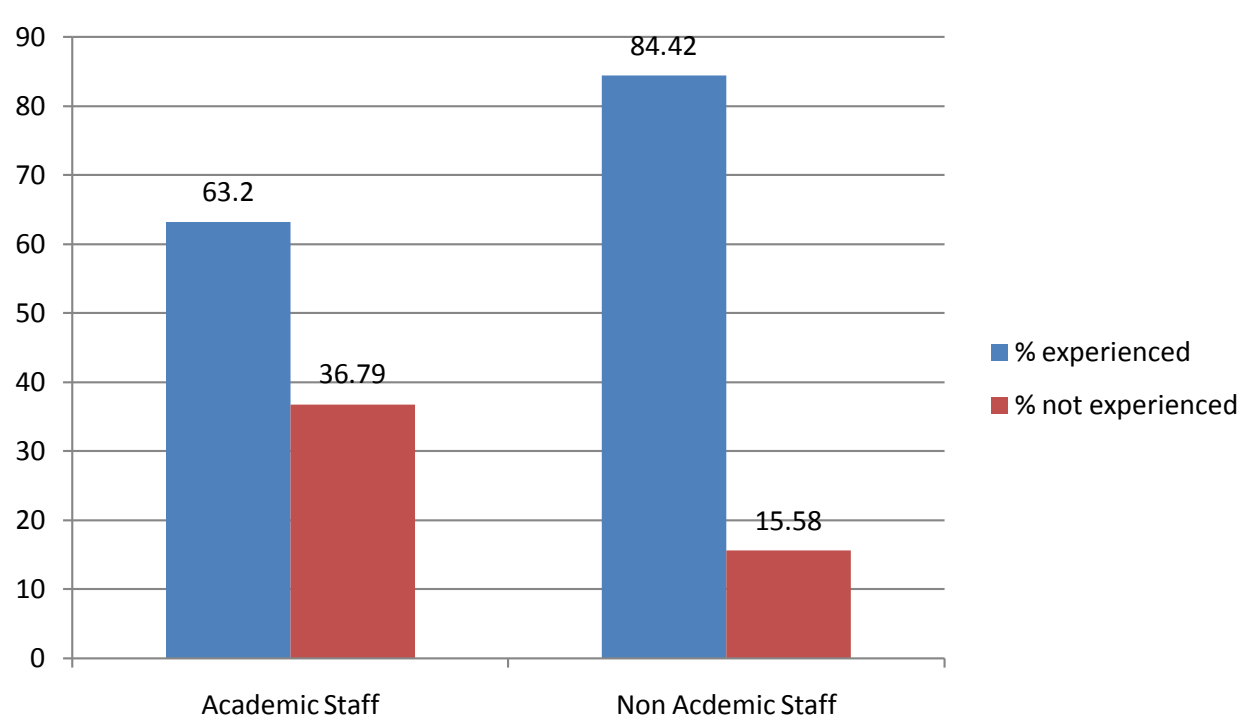

Figure 1. Showing percentage distribution of bullying among academic and non-academic staff of the University of Port Harcourt.

Table 6. Showing percentage suggested possible solutions that could reduce psychosocial hazards at workplaces in the University of Port Harcourt.

\begin{tabular}{ccc}
\hline S/N & ITEMS & Percentage responses (\%) \\
\hline 1 & Enlightenment of University workers (EUW) & $351(58.70 \%)$ \\
2 & Periodic in-service training (PIT) & $413(69.06 \%)$ \\
3 & $\begin{array}{c}\text { Introduction of occupational health and safety } \\
\text { programmes in the university (IOHSP) }\end{array}$ & $289(48.33 \%)$ \\
4 & Others (O) & $13(2.17 \%)$ \\
\hline
\end{tabular}

psychosocial hazards $(\mathrm{p}=0.041)$.

From the study, males were predominant. This is supported by previous study [23] [24]. This may equally simply reflect the recruitment pattern of the University. However, more females tended to have experienced psychosocial hazards reflecting reports in available literature [25] [26]. Majority of the respondents had tertiary education reflecting the fact that this is a tertiary institution of learning and as such most of the recruitment will be based on possession of a tertiary level degree. This may also be related to why majority of the respondents were academic staff.

The study found that those with lower level of education (lower academic qualification) experience higher prevalence of bullying compared to those who possess higher academic qualification. This may be a reflection of the fact that those with higher level of education will naturally be placed at higher position and as such would play the role of bosses and have tendency to give order, command and possibly exert rulership which may sometime be unfriendly over their subordinates. The relationship between level of education and experience of psychosocial hazards was found to be statistically significant $(\mathrm{p}=0.001)$. This finding is consistent with previous studies which have noted that experience of psychosocial hazards is more prevalent in lower socioeconomic 
occupations and disadvantaged occupational classes [2] [27] [28], adding that indeed, the lower the socioeconomic position, the higher the risk of exposure to adverse and stressful working conditions [29] [30], and also more vulnerable to poorer health [28].

Majority of the respondents were indigenes of Rivers State. This may simply be a reflection of the fact that the University is situated in Rivers State. However, there was a statistical relationship between ethnicity and experience of bullying in this study $(\mathrm{p}=0.038)$. This finding agrees with earlier documentation that for minority groups, ethnic discrimination is a stronger predictor of health outcomes than are traditional job stresses [31].

Duration in employment and category of staff both did not show any statistically significant relationship with experience of bullying. However, the study found that bullying was more experienced by workers with shorter duration of stay in employment than the longer staying staff. A possible explanation to this observation is that the younger staff may still be new to their job, with little experience, more prone to making mistakes that may warrant yelling, and may not have known their rights adequately [3], at such may be vulnerable to undue intimidation and harassment.

Workplace bullying is defined as repeated unreasonable behaviour directed towards an employee or group of employees that creates a risk to health or safety of the worker [32]. Verbal abuse, a form of bullying, was found to be common among the workers and in majority of cases was being perpetrated by bosses. Verbal abuses commonly follow poor performances, nonchalant attitude, laziness, poor attention to work, late coming, absenteeism and outright mistakes on the part of the employee. Often, a worker may be experienced burnout whenever worked, and may begin to show inefficiency due diminishing return [33] [34]. This may also be a cause of verbal abuse. Excluding or isolating particular employees does occur but the rate of occurrence was low. Harassment or intimidation was found to be common among the workers and were also mostly perpetrated by bosses.

Work place bullying could be a reflection of the personality of the perpetrators [32]. Anger laden individual or a perfectionist may often be quick to unleach verbal abuse on a staff. Very rarely, younger staff, have out of accumulated anger, frustration or perceived victimization, being verbally abusive to a boss. Often, this may in turn lead to threat of dismissal or outright dismissal. In either way, it is clearly identified as psychosocial hazard.

Assigning or delegating tasks that are impossible for the employee to successfully complete, changing work schedule with the deliberate intention of inconveniencing particular employees, and threats of dismissal were also found among the workers. All these could be used as instrument of victimization by bosses. Excluding particular employee was also found from the study. This commonly occurs where a more experienced staff wants to hoard a particular knowledge from a younger or newly engaged employee. Even though a single incident does not constitute bullying, one-off incidents should not be overlooked, as the tendency for subsequent occurrences is there.

Interestingly, occurrence of one form of workplace bullying or abuse can fuel or trigger the occurrence of another [35]. For instance, a boss who perceives that a particular younger worker is disrespectful to him or her can decide to exercise any of the forms of bullying to the affected younger staff.

Workplace bullying creates an unsafe working environment [36] [37], and this may be responsible for some of the below-expectations performance by some workers. Similarly, adverse and stressful working environment can predispose to other physical illnesses particularly cardiovascular disorders including hypertention, coronary heart diseases [38]-[40] and myocardiac infarction [41]. For instance, strong relationship has been established between depression and anxiety and occurrence of cardiovascular disorders [42]. This is due to amplification of the sympathetic system.

Earlier study has remarked that stress resulting from verbal abuse is particularly common in work places [31]. Hoel et al. (2001) in at the same study estimated that at least 10\% of European workers are currently subjected to bullying at work places. Exposure to workplace bullying is commonly associated with anxiety, depression, sometimes with suicidal ideation, insomnia and stress [31] [43]. This is also in agreement with another study that found significantly greater proportion of respondents in the high stress group agreeing that they had been physically or emotionally affected by bullying at work [44]. This may be responsible for the poor performance of some employees, as depression slows down mentation, psychomotor activity, memory, alertness, decreases energy and ultimately reduces performance and productivity [43] [45] [46], while anxiety causes restlessness, feeling on edge and poor attention and concentration [42].

A study had earlier noted that up to $40 \%$ of subjects who were experiencing bullying in a large scale Norwegian survey had contemplated suicide [36]. The contemplation of suicide may come as a result of declining 
performance and productivity, tendency to making mistakes, forgetfulness occasioned by the stress of bullying and or anxiety or depression and to worsen it all, threat of dismissal may follow all these cascades. So, is like a vicious cycle experienced by the employee.

Ironically, some employers erroneously believed that certain forms of bullying are targeted at busting performance of employee. Employers should make it a point of duty, so far as is reasonably practicable, that risks to health and safety of the worker from bullying are eliminated or reduced. Employees equally have duties under the OHS Act 2004 to take reasonable care of their own and other's health and safety and to cooperate with employers in terms of steps that must be taken to comply with a requirement under that Act.

Responses related to mental health include depression, anxiety and emotional problems, suicide or suicidal behaviours and general mental disorders [47] [48]. They have all been found to have great negative impact on work performance and productivity [49]. Psychosocial hazards including workplace stress equally affect the workers wellbeing and quality of life [50]. Physical and other environmental hazards can also cause or worsen already existing psychological problem, for example environmental noise and pollution. In this instance, the activities of oil exploration that go on in the Niger Delta may probably not make the environment safe enough. However, the noise level within the university is relatively low.

Work place bullying as psychosocial hazards are more complex, and so they have the greater potential to harm. They can cause harm both to psychological and psychosomatic states. With traditional hazards you only have physical problems. A good psychological working environment can buffer the consequences of poor working conditions [51]. Studies have confirmed the notion of the interrelationships of physical and psychosocial risks and their impact on workers' health [49]. Bullying as psychosocial hazards can have an impact on physical wellness. You cannot address the one without the other.

From the study, majority of cases of all forms of bullying were perpetrated by bosses. It follows naturally that since bosses are at higher ranks and status compared to their subordinates, the latter are much more likely to be victims of these forms of psychosocial hazards. Occasionally, the bosses use them with the intention of corrective measures, but they rather have often been found to be counter-productive [52].

\section{Recommendations}

Based on the findings from this study, the following are therefore recommended to the University management as appropriate measures and steps that could be taken to reduce the occurrence and burdens of bullying as psychosocial hazards in the University workplaces. They include the following:

1) Organising periodic in-service training (PIT) for staff of the University. Such training will focus on psychosocial hazards and occupational safety at workplaces.

2) Regular Enlightenment of University workers (EUW) and special orientation programmes be done for all newly employed staff.

3) Introduction of occupational health and safety programmes into the educational curriculum of the University. This will also provide avenues to acquire knowledge of occupational safety and health for both teaching and non-teaching staff, particularly those who may wish to take up one academic programme or the other within the University.

4) Immediate establishment of an Occupational risk and hazard management/Occupational rehabilitation centre.

\section{Conclusion}

The findings from this study revealed that the occurrence of bullying among the workers at the University of Port Harcourt is common. A number of preventable risk factors were identified. The results indicate that there is urgent need for the University to institute appropriate occupational health and safety measures to reduce the harmful occurrences of psychosocial hazards in the institution in order to improve the working environment, and consequently workers health and wellbeing as well as overall productivity.

\section{References}

[1] Melamed, S., Yekutieli, D., Froom, P., Kristal-Boneh, E. and Ribak, J. (1999) Adverse Work and Environmental Conditions Predict Occupational Injuries-The Israeli Cardiovascular Occupational Risk Factors Determination in Israel (CORDIS) Study. American Journal of Epidemiology, 150, 18-26.

http://dx.doi.org/10.1093/oxfordjournals.aje.a009913 
[2] Schrijvers, C.T.M., van de Mheen, H.D., Stronks K. and Mackenbach, J.P. (1998) Socioeconomic Inequalities in Health in the Working Population: The Contribution of Working Conditions. International Journal of Epidemiology, 27, 1011-1018. http://dx.doi.org/10.1093/ije/27.6.1011

[3] Takala, J. (2002) Life and Health Are Fundamental Rights for Workers (Interview). Labour Education, 1, 1-7.

[4] Dollard, M.F. (2006) Throwaway Workers. InPsych, 28, 8-12.

[5] Dollard, M.F. and Knott, V. (2004) Incorporating Psychosocial Issues into Our Conceptual Models of OHS. Journal of Occupational Health and Safety Australia and New Zealand, 20, 345-358.

[6] Stebbins, P., Thatcher, S. and King, R. (Speakers) (2005) Work Related Stress: HR, OH\&S and Legal Strategy (CD Recording). PsyHealth Media, Brisbane.

[7] Dollard, M.F. and Walsh, C. (1999) Illusory Correlation: Is Work Stress Really Worse in the Public Sector? Journal of Occupational Health and Safety Australia and New Zealand, 15, 219-229.

[8] Rydstedt, L.W., Ferrie, J. and Head, J. (2006) Is There Support for Curvilinear Relationships between Psychosocial Work Characteristics and Mental Well-Being? Cross-Sectional and Long-Term Data from the Whitehall II Study. Work \& Stress, 20, 6-20. http://dx.doi.org/10.1080/02678370600668119

[9] World Health Organization (2001) Mental Health in Europe. Regional Office for Europe, WHO, Copenhagen.

[10] Caulfield, N., Chang, D., Dollard, M.F. and Elshaug, C. (2004) A Review of Occupational Stress Interventions in Australia. International Journal of Stress Management, 11, 149-166. http://dx.doi.org/10.1037/1072-5245.11.2.149

[11] Ettner, S.L. and Grzywacz, J.G. (2001) Workers’ Perceptions of How Jobs Affect Health: A Social Ecological Perspective. Journal of Occupational Health Psychology, 6, 101-113. http://dx.doi.org/10.1037/1076-8998.6.2.101

[12] Senol-Durak, E., Durak, M. and Gencoz, T. (2006) Development of Work Stress Scale for Correctional Officers. Journal of Occupational Rehabilitation, 16, 153-164. http://dx.doi.org/10.1007/s10926-005-9006-z

[13] Kinman, G. and Jones, F. (2005) Lay Representations of Workplace Stress: What Do People Really Mean When They Say They Are Stressed? Work \& Stress, 19, 101-120. http://dx.doi.org/10.1080/02678370500144831

[14] De Bruin, G.P. and Taylor, N. (2005) Development of the Sources of Work Stress Inventory. South African Journal of Psychology, 35, 748-765. http://dx.doi.org/10.1177/008124630503500408

[15] Giuffrida, A., Iunes, R. and Savedoff, W. (2002) Occupational Risks in Latina America and the Caribbean: Economic and Health Dimensions. Health Policy \& Planning, 17, 235-246. http://dx.doi.org/10.1093/heapol/17.3.235

[16] Rosenstock, L., Cullen, M.R. and Fingerhut, M.A. (2006) Disease Control Priorities in Developing Countries. J Occup Health, 1127-1145.

[17] World Health Organization (2007) Global Plan of Action for Workers' Health, 2008-2017. WHO, Geneva.

[18] Kamusora, P. (2006) Non-Decision Making in Occupational Health Policies in Developing Countries. International Journal of Occupational and Environmental Health, 12, 65-71. http://dx.doi.org/10.1179/oeh.2006.12.1.65

[19] Cox, T. and Cox, S. (1993) Psychosocial and Organizational Hazards: Monitoring and Control. Occasional Series in Occupational Health, No. 5. World Health Organization (Europe), Copenhagen.

[20] Awoyemi, A.O. and Kabir, M. (1997) Awareness about Occupational Hazards Among Doctors at a Hospital in Nigeria. Bioscience Research Communication, 9, 183-187.

[21] Araoye, M.O. (2004) Research Methodology with Statistics for Health and Social Science. Nathadex Publishers, Ilorin, 117-120.

[22] Wegman, D.H. (2006) Aging and Globalization. Medicina del Lavoro, 97, 137-142.

[23] Baker, C.N. (2005) Blue-Collar Feminism: The Link between Male Domination and Sexual Harassment. In: Gruber, J.E. and Morgan, P., Eds., The Company of Men: Male Dominance and Sexual Harassment, Northeastern University Press, Boston, 242-270.

[24] Premji, S. (2011) Building Healthy and Equitable Workplaces for Women and Men: A Resource for Employers and Workers Representatives. Protecting Workers’ Health Series No. 11, World Health Organization, Geneva.

[25] Duxbury, L. and Higgins, C. (2001) Work-Life Balance in the New Millennium: Where Are We? Where Do We Need to Go? CPRM Discussion Paper No. W|12, Canadian Policy Research Network, Ottawa.

[26] Heymann, J. (2006) Forgotten Families: Ending the Growing Crisis Confronting Children and Working Parents in the Global Economy. Oxford University Press, New York. http://dx.doi.org/10.1093/acprof:oso/9780195156591.001.0001

[27] Wright, E.O. (1997) Classes Count: Comparative Studies in Class Analysis. Cambridge University Press, Cambridge.

[28] Chandola, T. and Jenkinson, C. (2000) The New UK Statistics Socio-Economic Classification (NS-SEC); Investigating Social Class Differences in Self-Reported Health Status. Journal of Public Health Medicine, 22, 182-190. http://dx.doi.org/10.1093/pubmed/22.2.182 
[29] Rose, D. and O’Reilly, K., Eds. (1997) Constructing Classes: Towards a New Social Classification for the UK. Office of National Statistics, London.

[30] Siegrist, J. and Marmot, M. (2004) Health Inequalities and the Psychosocial Environment—Two Scientific Challenges. Social Science \& Medicine, 58, 1463-1473. http://dx.doi.org/10.1016/S0277-9536(03)00349-6

[31] Hoel, H., Sparks, K. and Cooper, C. (2001) The Cost of Violence/Stress at Work and the Benefits of a Violence/StressFree Working Environment. Report commissioned by the International Labour Organization, University of Manchester, Manchester.

[32] Ortega, A., Høgh, A., Pejtersen, J.H., Feveile, H. and Olsen, O. (2009) Prevalence of Workplace Bullying and Risk Groups: A Representative Population Study. International Archives of Occupational \& Environmental Health, 82, 417426. http://dx.doi.org/10.1007/s00420-008-0339-8

[33] Schaufeli, W.B. and Greenglass, E.R. (2001) Introduction to Special Issue on Burnout and Health. Psychology and Health, 16, 501-510. http://dx.doi.org/10.1080/08870440108405523

[34] Borritz, M., Rugulies, R., Bjorner, J.B., Villadsen, E., Mikkelsen, O.A. and Kristensen, T.S. (2006) Burnout among Employees in Human Service Work: Design and Baseline Findings of the PUMA Study. Scandinavian Journal of Public Health, 34, 49-58. http://dx.doi.org/10.1080/14034940510032275

[35] Rospenda, K. (2002) Workplace Harassment, Services Utilization, and Drinking Outcomes. Journal of Occupational Health Psychology, 7, 141-155. http://dx.doi.org/10.1037/1076-8998.7.2.141

[36] Einarsen, S., Raknes, B.I. and Matthiesen, S.M. (1994) Bullying and Harassment at Work and Their Relationships to Work Environment Quality-An Exploratory Study. European Work and Organizational Psychologist, 4, 381-401. http://dx.doi.org/10.1080/13594329408410497

[37] Stansfeld, S. and Candy, B. (2016) Psychosocial Work Environment and Mental Health—A Meta-Analytic Review. Scandinavian Journal of Work Environment and Health, 32, 443-462.

[38] Greenlund, K., Liu, K., Knox, S., McCreath, H., Dyer, A. and Gardin, J. (1995) Psychosocial Work Characteristics and Cardiovascular Disease Risk Factors in Young Adults: TThe CARDIA Study. Social Science \& Medicine, 41, 717-723. http://dx.doi.org/10.1016/0277-9536(94)00385-7

[39] Melamed, S., Yekutieli, D., Froom, P., Kristal-Boneh, E. and Ribak, J. (1999) Adverse Work and Environmental Conditions Predict Occupational Injuries-The Israeli Cardiovascular Occupational Risk Factors Determination in Israel (CORDIS) Study. American Journal of Epidemiology, 150, 18-26. http://dx.doi.org/10.1093/oxfordjournals.aje.a009913

[40] Schnall, P., Belkic, K., Landsbergis, P.A. and Baker, D. (2000) Why the Workplace and Cardiovascular Disease? Occupational Medicine: State-of-the-Art Reviews, 15, 1-6.

[41] László, K.D., Ahnve, S., Hallqvist, J., Ahlbom, A. and Janszky, I. (2010) Job Strain Predicts Recurrent Events after a First Acute Myocardial Infarction: The Stockholm Heart Epidemiology Program. Journal of Internal Medicine, 267, 599-611. http://dx.doi.org/10.1111/j.1365-2796.2009.02196.x

[42] Sadock, V.J. and Sadock, V.A. (2007) Kaplan and Sadock’s Synopsis of Psychiatry.

[43] Bonde, J.P. (2008) Psychosocial Factors at Work and Risk of Depression: A Systematic Review of the Epidemiological Evidence. Occupational \& Environmental Medicine, 65, 438-445. http://dx.doi.org/10.1136/oem.2007.038430

[44] Smith, A., Johal, S., Wadsworth, E., Smith, G. and Peters, T. (2000) The Scale of Occupational Stress: The Bristol Stress and Health at Work Study. Health \& Safety Executive Research Report No. CRR 265, HSE Books, Sudbury.

[45] Tennant, C. (2001) Work-Related Stress and Depressive Disorders. Journal of Psychosomatic Research, 51, 697-704. http://dx.doi.org/10.1016/S0022-3999(01)00255-0

[46] Melchior, M., Caspi, A., Milne, B.J., Danese, A., Poulton, R. and Moffitt, T.E. (2007) Work Stress Precipitates Depression and Anxiety in Young, Working Women and Men. Psychological Medicine, 37, 1119-1129. http://dx.doi.org/10.1017/S0033291707000414

[47] Warr, P.B. (1992) Job Features and Excessive Stress. In: Jenkins, R. and Coney, N., Eds., Prevention of Mental Ill Health at Work, HMSO, London, 201-205.

[48] Lehtinen, V., Riikonen, E. and Lahtinen, E. (1997) Promotion of Mental Health on the European Agenda. National Research and Development Centre for Welfare and Health, Finland.

[49] Cox, T. and Griffiths, A. (2010) Work-Related Stress: A Theoretical Perspective. In: Leka, S. and Houdmont, J., Eds., Occupational Health Psychology, Wiley- Blackwell, Chichester, 31-56.

[50] Bin Nordin, R., Bin Abdin, E. and Naing, L. (2008) Working Conditions, Self-Perceived Stress, Anxiety, Depression and Quality of Life: A Structural Equation Modelling Approach. BMC Public Health, 8, 48.

[51] Dollard, M.F. and Karasek, R. (2010) Building Psychosocial Safety Climate: Evaluation of a Socially Coordinated 
PAR Risk Management Stress Prevention Study. In: Houdmont, J. and Leka, S., Eds., Contemporary Occupational Health Psychology: Global Perspectives on Research and Practice, Wiley Blackwell, Chichester, 208-234. http://dx.doi.org/10.1002/9780470661550.ch11

[52] Kortum, E. (2007) Work-Related Stress and Psychosocial Risks: Trends in Developing and Newly Industrialized Countries. The Global Occupational Health Network Newsletter, Special Issue (July), 3-6. 


\section{Appendix}

\section{Study Questionnaire}

Please, kindly tick the appropriate box as applicable.

\section{Section A: Biodata}
1. $\quad$ Age: (a) $18-25 \square$
(f) $66-75$
(b) 26 - 35
(c) 36 - 45
(d) 46 - 55
(e) 56 - $65 \square$

2. Sex: (a) Male $\square$

(b) Female $\square$
3. Marital Status: (a) Married $\square$
(b) Single
(c) Separated
(d) Divorce
(e) Widow

4. Level of Education: (a) Primary
(b) Secondary
(c) Tertiary
(b) Islam $\square \quad$ (c) Traditionalist $\square$
5. Religion: (a) Christianity
(b) Ogoni
(c) Kalabari $\square$
(d) Etche
(e) Others

7. Living Place: (a) Urban

(b) Semi Urban $\square$

(c) Rural

8. Faculty Department Unit

9. Employment status/Rank: (1) Academic (2) Non academic $\square$
If 1, indicate; (a) Graduate Assistant
(b)Assistant Lecturer $\square$
(c) Lecturer II

(e) Senior Lecturer

(f) Reader $\square$

(d) Lecturer I $\square$

(i) Staff on Sabbatical leave
If 2 , indicate which type;
(d) Computer operator $\square$
(b) Technician
(c) Dispatcher $\square$

(h) Senior Admin Officer

(g) Professor $\square$

(h) Contract Staff $\square$

10. Category of Staff: (a) Junior Staff $\square \quad$ (b) Senior Staff $\square$

11. How long have you been employed in this institution?
$2-10$
$11-20$
$21-30$
$31-40$
$41-50$
$>50$

\section{Section B:}

12. Assessment of Bullying in Workplaces

Indicate which of the following hazards you have been exposed to while working in this institution. Note: You can tick more than one if applicable.

\begin{tabular}{|c|c|c|c|c|c|c|}
\hline \multirow[t]{2}{*}{$\mathbf{S} / \mathbf{N}$} & \multirow[t]{2}{*}{ Type } & \multirow[t]{2}{*}{ Perpetrator } & \multicolumn{4}{|c|}{ Rate of Occurrence } \\
\hline & & & $\begin{array}{l}\text { Very } \\
\text { regular }\end{array}$ & Regular & Occasional & $\begin{array}{c}\text { Rare } \\
\text { (Does not } \\
\text { occur) }\end{array}$ \\
\hline
\end{tabular}

Workplace Bullying;

a. Verbal abuse

b. Excluding or isolating particular employees

c. Harassment or intimidation

d. Assigning meaningless tasks unrelated to the employee's job

1.

Assigning tasks that are impossible for the employee to successfully complete.

f. Changing work rosters with the deliberate intention of inconveniencing particular employees.

g. Threats of dismissal.

$\begin{array}{ll}\text { Subordinate } \square & \text { Boss } \square \\ \text { Subordinate } \square & \text { Boss } \square \\ \text { Subordinate } \square & \text { Boss } \square \\ \text { Subordinate } \square & \text { Boss } \square \\ \text { Subordinate } \square & \text { Boss } \square \\ \text { Subordinate } \square & \text { Boss } \square \\ \text { Subordinate } \square & \text { Boss } \square\end{array}$

\section{Section C:}

13. Assessment of Risk Factors for Bullying in Workplaces

Please, indicate which of the following you think is/are the likely risk factors for the identified Social hazards above. Note: You can tick more than one if applicable.I

$\square$ Changes in the Working Population

$\square$ Job Content 


\section{$\square$ Workload}

$\square$ Work Pace \& Forced pace of work

$\square$ Work Schedule: Shift Work, Long Work Hours and Overtime

$\square$ Environment and Equipment

$\square$ Organisational culture and function

$\square$ Interpersonal Relationships at Work (Relationships with Superiors, Subordinates and Colleagues)

$\square$ Violence, threat of violenceand bullying at work

$\square$ Career Development

$\square$ Home-Work Interface

$\square$ Too busy

$\square$ Too High Expectations or Goals

$\square$ Lack of Possibilities to Advance

$\square$ Lack of Job and Workplace Orientation

$\square$ Lack of Job Descriptions and Responsibilities

$\square$ Uncertainty of Employment

$\square$ Poor Management or Organisation

$\square$ Poor Working Atmosphere

$\square$ Lack of Interaction

$\square$ Lack of Social Support

$\square$ Lack of Possibilities to Influence decision making.

\section{Section D}

13. Suggest possible solutions;

Enlightenment of University workers

$\square$ Periodic in-service courses

$\square$ Introduction of occupational health and safety programmes in the University

$\square$ Others 